\title{
Competition on the labour market : an analysis of the position of types of training
}

Citation for published version (APA):

van der Velden, R. K. W., \& Borghans, L. (1993). Competition on the labour market : an analysis of the position of types of training. Researchcentrum voor Onderwijs en Arbeidsmarkt, Faculteit der Economische Wetenschappen. ROA Research Memoranda No. 5E https://doi.org/10.26481/umaror.199305E

Document status and date:

Published: 01/01/1993

DOI:

10.26481/umaror.199305E

Document Version:

Publisher's PDF, also known as Version of record

\section{Please check the document version of this publication:}

- A submitted manuscript is the version of the article upon submission and before peer-review. There can be important differences between the submitted version and the official published version of record.

People interested in the research are advised to contact the author for the final version of the publication, or visit the DOI to the publisher's website.

- The final author version and the galley proof are versions of the publication after peer review.

- The final published version features the final layout of the paper including the volume, issue and page numbers.

Link to publication

\footnotetext{
General rights rights.

- You may freely distribute the URL identifying the publication in the public portal. please follow below link for the End User Agreement:

www.umlib.nl/taverne-license

Take down policy

If you believe that this document breaches copyright please contact us at:

repository@maastrichtuniversity.nl

providing details and we will investigate your claim.
}

Copyright and moral rights for the publications made accessible in the public portal are retained by the authors and/or other copyright owners and it is a condition of accessing publications that users recognise and abide by the legal requirements associated with these

- Users may download and print one copy of any publication from the public portal for the purpose of private study or research.

- You may not further distribute the material or use it for any profit-making activity or commercial gain

If the publication is distributed under the terms of Article $25 \mathrm{fa}$ of the Dutch Copyright Act, indicated by the "Taverne" license above, 


\title{
COMPETITION ON THE LABOUR MARKET. \\ AN ANALYSIS OF THE POSITION OF \\ TYPES OF TRAINING
}

ROA-RM-1993/5E

\author{
Rolf van der Velden, Lex Borghans
}

RESEARCH CENTRE FOR EDUCATION AND THE LABOUR MARKET

Faculty of Economics and Business Administration

Rijksuniversiteit Limburg

Maastricht, November 1993 


\section{CIP-GEGEVENS KONINKLIJKE BIBLIOTHEEK, DEN HAAG}

Velden, Rolf van der

Competition on the labour market: an analysis of the position of types of training / Rolf van der Velden, Lex Borghans. - Maastricht: Research Centre for Education and the Labour Market, Faculty of Economics and Business Administration, Rijksuniversiteit Limburg. - ([Report] / Researchcentrum voor Onderwijs en Arbeidsmarkt, ISSN 0922-8098; ROA-RM-1993/5E) Met lit. opg. ISBN 90-5321-117-9

Trefw.: beroepsonderwijs en arbeidsmarkt. 
CONTENTS

Page

1. INTRODUCTION 1

2. SELECTION AND ALLOCATION ON THE LABOUR MARKET 3

3. DATA AND METHOD 6

4. ANALYSIS 9

5. CONCLUSIONS 14

$\begin{array}{lr}\text { REFERENCES } & 16\end{array}$

$\begin{array}{ll}\text { APPENDIX } & 18\end{array}$ 


\section{INTRODUCTION ${ }^{1}$}

There is no exclusive relation between a type of training and an occupation. On the one hand graduates can hold different occupations, while on the other hand employers can recruit graduates from different types of training. Although in general the concept of an exclusive relation between training and occupation might be called 'naive' and unrealistic (Van Hoof and Dronkers, 1980), the reverse concept of total flexibility can also be called unrealistic. As De Grip and Heijke (1988) point out, most types of training will take a position between these two extremes. This means that types of training will usually give access to a limited number of occupations and, reversely, employers will have some substitution possibilities when recruiting personnel for a particular occupation. Exceptions exist in the professionalised segments of the iabour market, like health care and education, where recruitment for a job is governed by strict rules and criteria, the most important being the possession of certain training certificates. Here the types of training involved have an exclusive occupational domain and, by rule, there is no competition from outside.

For a good understanding of the processes which take place at the labour market knowledge about the structure of the labour market and its segments is very important. The labour market situation of one type of training can not be understood without taking into account the labour market situation of other types of training. On the other hand, however, one must not neglect the fact that substitution possibilities and therefore competition between types of training are limited. Therefore, to grasp the functioning of the labour market, e.g. the formation of wages, education specific levels of unemployment, allocation, or (self-)selection processes, it is essential to have an adequate description of the actual segmentation of the labour market.

Mostly, this segmentation of the labour market, if recognised, is brought into the analysis on theoretical grounds. These concepts involve a priori distinctions like primary and secondary labour market or the level of education. Hartog (1993), shows to what problems these a priori categories lead in the study of self-selection, which is a very relevant issue for the investigation of the distribution of capabilities over people and therefore important for the explanation of earnings differentials. Hartog therefore stresses the importance of investigating the actual labour market segments empirically. Such empirical observed segments will provide insight in the competition structure of the labour market which is more complex than most theoretical structures, and also allows for the possibility that the segmentation structure might change in time due to occupational changes or labour market circumstances.

The aim of this paper is to analyse the competition between graduates from different types of training on the labour market, using data from the Dutch Labour Force Survey of 1979 and 1985. Specific methods will be introduced to analyse the competition structure and the

1. A preliminary version of this paper has been presented at the 1992 meeting of the ISA Research committee on Social Stratification and Mobility in Trento, Italy. The authors like to thank Andries de Grip for his useful comments, and José le for computational assistance. 
changes that have taken place in this structure between 1979 and 1985 . We will show that the labour market is segmented along qualification lines. Within each segment only a few types of training compete with each other and some segments can even be called monopolistic in the sense that they are the exclusive domain of only one type of training.

The analysis will offer a detailed description of the substitution possibilities on the labour market, both for supply and demand side. Besides its relevance for labour market research, as indicated above, this is important information for individual demanders and suppliers of labour market and policy makers:

1. For individual demanders and suppliers of labour the substitution possibilities indicate the risks they take when following a particular training or offering a particular job.

2. For policy makers the analysis of the substitution processes on the labour market will show the potentials for flexibility in particular segments of the labour market for particular types of training. It also shows the effects of horizontal and vertical differentiation in education. 


\section{SELECTION AND ALLOCATION ON THE LABOUR MARKET}

Economic and sociological literature usually distinguishes at least three different functions of education: ${ }^{2}$

a. The qualification function: following education makes people more productive for their future jobs.

b. The selection function: education serves as a sorting machine where only those are selected who possess the required qualifications.

c. The allocation function: education is an important determinant of the allocation of individuals to particular jobs on the labour market.

We take the position that the latter two functions can only be understood in conjunction with the qualification function, i.e. education can perform its selection and allocation function only because it has a qualification function. ${ }^{3}$

This qualification can take two different forms (Schultz, 1961; Becker, 1964):

1. General qualifications or generic human capital: this is associated with general cognitive development, learning behaviour, general social abilities etc.

2. Specific qualifications or specific human capital: this is associated with the specific skills which are needed for a particular job.

The distinction between generic and specific human capital parallels the vertical and horizontal differentiation in the educational system, where the amount of generic human capital is closely related with the number of years of education, while specific human capital is more linked with the sector of education. This identification of generic qualifications with the length of the training period is not trivial, but presumes some kind of optimal investment behaviour of students. Students who get more years of training will be those who possess more training capability (selection argument) or will besides their specific training also invest in generic human capital since they will have more benefit from it.

It is the combination of generic and specific human capital that determines an individual's chances in the selection processes on the labour market. As Glebbeek (1983) points out, for large parts of the labour market - those sectors facing efficiency pressures - , employers seek to minimise the expected training costs of their employees. Thus they rank applicants for a job, according to their assessed training costs (Thurow, 1975). These training costs cannot directly be assessed, but are indicated by simple screening devices like education and age. Education

2. Some sociologists point out that education also serves a fourth function: the legitimation function in reproducing social inequality.

3. This is not without debate. Thurow (1975) e.g. takes the position that education has a screening function, without actually qualifying people for their jobs. Apart from unskilled labour, this proposition can hardly be called realistic. If education really does not improve students' qualifications, with regard to its length, it would be an extremely inefficient way to select or allocate people. 
probably serves as the most important screening device. According to Glebbeek the expected training costs of graduates from a particular training are a function of three components:

1. learning ability: the average expected learning ability of the graduates of a given type of training (the amount of generic human capital);

2. exclusivity: the extent to which a type of training has an advantage in the exclusive supply of the required skills for a certain function (the amount of specific human capital);

3. incompetence risks: the extent to which graduates do not control the required skills, in combination with the sensitivity of the function to incompetence of the job holder.

According to Glebbeek, the labour market position of a type of training is better when its exclusivity is high, the incompetence risk low, and the average learning ability is good. Conversely, the less advantage a type of training offers in the exclusive supply of the required skills, the more sensitive its labour market position will be to indications of the learning ability and quality variation of its graduates.

On the one hand types of training differ in the ratio of generic versus specific human capital offered to their students as well as in the amount of quality control or selectiveness of their curriculum. On the other hand, jobs differ in the amount of generic versus specific human captital required as well as the sensitivity of the job to incompetence of the job holder.

This implicates that ideally three types of segments in the labour market can be distinguished. In the first place, those segments where there is a strong emphasis an specific skills, which can only be acquired by specific training. ${ }^{4}$ This parallels what Lutz and Sengenberger (1974) have called the 'craft specific' segment of the labour market. Technical jobs are a typical example of this type of segment. The specific skill requirements make it almost impossible to substitute between different types of training at the same level. For it is not training in general, but training in a specific subject that makes a person better qualified for these particular jobs. Substitution is therefore more likely to occur with similar types of training of the next higher or lower level. These segments are therefore determined by the sector of education, rather than the level of education.

The second type involves those segments where there is a strong emphasis on general skills. This is not to say that in performing the job, specific skills are not required. The required skills may be too firm-specific to be taught in a regular training or - because of technological developments - there is uncertainty about the specific skills needed in the future. In both cases the employer will tend to emphazise the general learning ability. As mentioned before, people with a high level of educational attainment will tend to possess (initially or due to

4. It is important to note that in economic and sociological resarch very little attention has been paid to the role of the specific sector of education. The main stream of research has concentrated on the effects of years of education or level of educational attainment on variables like income (Hartog et al, 1985), occupational status (Ganzeboom and De Graaf, 1989) or unemployment (Meesters and Van de Pol, 1988), while neglecting the effects of sector of education. However the sector of education may well overshadow the effect of the number of years of education as Glebbeek and Mensen (1986) and Bakker (1987) have shown. In the manpower forecasting literature, however, the sector of education plays a crucial role (Blaug, 1967, Van Eijs, 1993). 
training) more general learning capabilities. This selectivity is informative for employers and therefore screening (Spence, 1973; Stiglitz, 1975) becomes important and the level of education is judged as more relevant than the specific sector of education. Competition will therefore ideally be restricted to one level of education, involving multiple sectors of education. These types of training are only gradually different, with overlapping labour market segments.

The third type consists of segments where there is a mutually exclusive relation between a type of training and an occupation. In contrast to the first two types of segments, in this segment a type of training will meet no competition from others. This type is typically to be found in the professionalised segments of the labour market where interest groupts or government regulate the access to particular jobs by setting certain training requirements. These educational credentials (Collins, 1979) serve as an admission ticket to the jobs in question. As a rule (and often enforced by law) there are no substitution possibilities, neither from other sectors of education nor from other levels. Conversely, however, people with these types of training might get employed outside their protected segment. The situation is therefore not symmetric.

The specific constellation of substitution possibilities within a segment is thus an indication of the weight put on specific human capital or generic human capital. If substitution involves only one sector of education and multiple levels, than the emphasis in that particular segment is on specific human capital. If substitution involves multiple sectors within one level of education, this refers to segments where people are screened on generic human capital. Many authors believe that, as a result of technological developments and firm-specific requirements, this screening on level of education has gained importance over the last two decades (Van Hoof, 1987). If there are no substitution possibilities, this refers to segments where acces to jobs is ruled by credentials. With the ongoing professionalisation of the labour market, this type of segment will also have extended over the years.

The questions we address in this article are:

1. To what extent can the labour market meaningfully be described as segmented by educational qualifications?

2. Is there a trend towards a higher level of screening on the level of education respectively is there a trend towards credentialism? 


\section{DATA AND METHOD}

The data for this paper stem from the Dutch Labour Force Surveys of 1979 and 1985 . These are national representative samples (approximately $2.5 \%$ of the population) by the Central Bureau of Statistics (CBS). From these two surveys a matrix of training by occupation is used. The educational background of the workers has been classified by the ROA-classification of education, which consists of 54 categories. The occupations have been classified according the 3-digit CBS-classification, which is based on the International Standard Classification of Occupations. The 3-digit classification entails 319 occupational titles (CBS, 1985).

This matrix education by occupation is used to investigate the competition structure of the Dutch labour market. A crucial assumption to justify this approach in that there is no distinction between the potential and the actual occupations of persons from a certain type of training. Theoretically, it might however be the case that a threat of entrance of people in a certain educational background influences the labour market conditions in certain occupations, without people really entering these occupations. Furthermore, persons with a certain type of training might have other occupational possibilities, which are not attractive at the moment, but might become an important alternative when their labour market position becomes worse.

Based on the information about the actual employment of people from a certain type of training the similarity between types of training can be measured. The actual analysis of this matrix cannot be done without some sort of data reduction. Factor analysis is chosen as a way to reduce the huge amount of information and to describe the underlying structure.

First a similarity matrix is produced in which the association between the different types of training is to be found. In this way the matrix 'training by occupation' is replaced by a matrix 'training by training'. Following Borghans (1992) the similarity between two types of training is defined as:

$$
S_{i, i i}=\frac{\sum_{j} P_{i j} P_{i i j}}{\sqrt{\sum_{j} P_{i j}^{2} \sum_{j} P_{i i j}^{2}}}
$$

in which $s_{i, i i}=$ similarity between training $i$ and training $i i$

$$
p_{i j}=\text { proportion of people with training } i \text { working in occupation } j
$$

This criterion, often used in cluster analysis (Lorr, 1983), measures the cosine of the angle between two vectors of distribution. If the distribution of two types of training $i$ and $i i$ is equal, than the measure will be +1 . If the distributions of the two types of training do not match at 
all, i.e. if people from two different types of education never have the same occupation, the similarity will equal zero. This similarity measure is used to measure the association between all pairs of types of training, thus resulting in an association matrix of types of training. The resulting matrix can be proven to be positive definite.

Factor analysis is mostly used to describe the association between variables. However it can also be used to describe the association between objects (Kim, 1975). The similarity matrix is therefore analysed with factor analysis, ${ }^{5}$ to yield a clear view on the underlying structure of competition on the labour market. The factors can be viewed as representing different segments of the labour market. Such segments consist of one or more occupations, for which a particular group of types of training gives access. The segmentation of the labour market is thus defined by the qualification structure of the workers: if one or more types of training share the same occupations, this is expressed by a separate factor on which these particular types of training have high loadings, while other types of training have low loadings on this factor.

According to the segmentation literature, mobility takes place mainly within segments, but not between segments. Segments are viewed as relatively isolated, with strict boundaries between them. This calls for a factor analysis in which the extracted factors are independent, and as no prior information exists on the underlying structure, principal component analysis is chosen above classical factor analysis. In this way the extracted factors represent segments of the labour market in such a way that competition is allowed within but not between the segments.

The number of factors which can meaningfully be extracted indicates the degree of segmentation on the labour market. In the case of a perfect exclusive relation between a type of training and an occupation, there will be as many factors as there are types of training, each with an eigenvalue of 1.00 . Of course, in reality a high degree of segmentation will produce eigenvalues smaller than 1.00, because even in a situation where access to an occupation is strictly reserved for graduates of a particular training, there will always be graduates of this training who hold other occupations. In the case of total flexibility (i.e. all types of training share the same distribution of occupations), only one factor will be extracted with an eigenvalue of 54 (i.e. the total number of types of training distinguished).

The loading of a type of training on an extracted factor indicates the importance of that segment for the training in question. High loadings mean that the segment is important for the training. The loadings also show which types of training compete with each other in the segment and which types of training dominate the segment. The eigenvalue of the factor represents the amount of competition: the more types of training are dependent on the same segment, the higher the eigenvalue of the factor in question and the more competition in that

5. Although factor analysis is intended to analyse correlation matrices, we will use it here to analyse the similarity matrix. As stated before, the similarity matrix can be proven to be positive definite, which is a main prerequisite for factor analysis. The similarity-index has the property that the principal component factor analysis explains a maximum amount of the Gini-Hirschman-dispersion of a type of education instead of the variance of its frequency in every occupation. 
segment exists. The total amount of competition on the labour market can likewise roughly be determined as:

$$
C=V-\frac{n-1}{N}=\frac{1+\sum_{\lambda_{i}>1}\left(\lambda_{i}-1\right)}{N}
$$

in which

$C=$ the amount of competition;

$V=$ the proportion 'explained' variance ${ }^{6}$ with extracted factors with an eigenvalue greater than 1.00 .

$\lambda_{i}=$ the eigenvalue of factor $i$.

$\mathrm{n}=$ the number of extracted factors with eigenvalue greater than 1.00

$N=$ total number of types of training

This competition-measure depends on the sum of the extent to which the factors exceed the eigenvalue 1.00. If there are only a few segments at the market which include many types of education, the competition-measure will be large.

The aim of the factor analysis is purely descriptive. There is no theoretical premise on which the number of factors to be extracted can be based. As the interest is more on a simplified reproduction of the competition structure (i.e. the factor structure), rather than in the assignment of a type of training to one particular factor, varimax rotation is chosen to obtain an optimal solution.

6. In fact the factors explain the Gini-Hirschman-dispersion of a type of education over the occupations, rather than its variance. For convenience, however, the term variance (see footnote 5) will be used throughout this paper. 


\section{ANALYSIS}

Table 1 gives the results of the factor analysis for both the 1979 and the 1985 data. Usually, an eigenvalue greater than 1.00 is used to determine the number of extracted factors. As this criterion would lead us to underestimate the number of segments where an exclusive relation between training and occupation exists, the threshold has arbitrarily been set at .50. In that case, types of training where a large percentage of the graduates occupies a particular segment of the labour market with little competition from other types of training, will be regarded as a separate segment. Of course, the lowering of the threshold also enlarges the chance of extracting factors which cannot be meaningfully interpreted.

Table 1. Results of the factor analysis for 1979 and 1985: general statistics

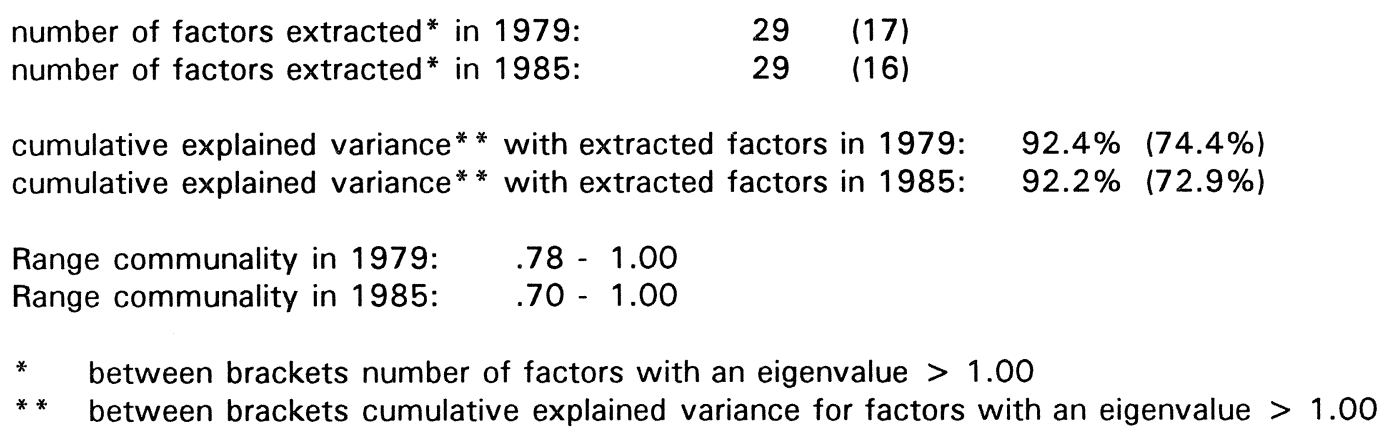

Both analyses extracted 29 factors. In the 1979 analysis 17 of these factors have an eigenvalue greater than 1.00 , corresponding with $74.4 \%$ of the variance. In the 1985 analysis these numbers are 16 and $72.9 \%$ respectively. Following our definition stated in section 3 , the total amount of competition on the labour market has thus remained the same. In 1979 the amount of competition was $(0.744-17 / 54) \times 100 \%=43 \%$. In 1985 the corresponding figure was $(0.729-16 / 54) \times 100 \%=43 \%$. This indicates that there is considerable openness on the labour market and that in general there is no exclusive relation between a type of training and an occupation. There is however a considerable degree of segmentation, but these segments usually involve more than one type of training as will be shown later. The degree of segmentation has remained the same in the 1979-1985 period.

The communalities of the different types of training range from .78 till 1.00 in the 1979 analysis, and from .70 till 1.00 in the 1985 analysis. This means that the distributions of all types of training is reasonably, and sometimes even very well, described by the extracted factors. This is mainly due to the low threshold of .50 . If the threshold was set at 1.00 , one out of seven types of training would have had communalities lower than .50. As we shall see later, these particular types of training all have an exclusive occupational domain. 
Not all extracted factors could be meaningfully interpreted. In the 1979 analysis two factors refered to educational rest-categories, while one factor had no significant loading of any training. In the 1985 analysis again two factors refered to educational rest-categories, while two factors had no significant loadings of any training. Tables 2 till 25 present the extracted factors that could be interpreted. The factors are presented in descending order of the eigenvalues in the 1979 analysis. The factor structure between the two years is quite alike. In a few cases however, the 1979 analysis yielded two factors, where the 1985 analysis yielded one factor and vice versa. This is indicated in the tables. As a general rule, all types of training are presented which have loadings higher than .30 .

The largest segment to be distinguished are the economic administrative occupations (appendix, table 2). It is the main segment for the general secondary education (lower and higher level), the commerce and administration types of training in lower (LVE), intermediate (IVE) and higher vocational education (HVE), as well as for the administrative legal and fiscal types of training at the intermediate and (only for 1985) the higher vocational level. It is striking that the types of training in this segment vary from lower vocational level to higher vocational level. This is probably partly an artefact of the classification. The CBS-classification is not very elaborate for administrative occupations: e.g. management secretaries and typists belong to the same 3-digit occupational category, although they quite clearly differ in qualification requirements. Nevertheless, it seems to be a segment where the boundaries between sectors of education are not very sharp: there is a huge amount of competition between general types of training, commerce and administration types of training. ${ }^{7}$ This indicates a segment where emphasis is put on generic rather than specific human capital. Furthermore the competition between the different levels indicates that there is a great overlap in occupations held by people with a different level of educational attainment. This may indicate processes of displacement and under-utilisation. The fact that the loading of HVE Administrative, Legal and Fiscal grows from .32 in 1979 to .63 in 1985, points in the same direction: as general unemployment rates rise from $6.5 \%$ in 1979 to $15.8 \%$ in 1985 , the job requirements set by employers seem to get higher.

The second largest segment is formed by the teaching professions (appendix, table 3 ). In the 1979 analysis seperate factors are extracted for HVE Teacher Training (mainly consisting of teachers in primary education) and the academic types of training (mainly teachers in secondary and tertiary education). In the 1985 analysis only one factor is extracted. This is due to the growing number of graduates with HVE Teacher Training who become teacher in secondary education. Surprising is the strong position in this segment for the academic education (AE) in Arts and especially mathematics and natural sciences. This indicates the importance of teaching professions for these types of training. Although this segment seems to emphasise generic human capital (competition within one level between different sectors of schooling), this is an

7. The position of IVE Transport, Harbour \& Telecommunications refers to the administrative trainings in this type of education. As the educational rest-categories may vary between the years, their loadings will not be seperately discussed. 
artefact of the classification: all teaching professions in secondary and tertiary education fall into one occupational category. Of course, there is no real competition between e.g. a teacher of mathematics and a teacher of history. In fact, this segment is a good example of credentialism: access to jobs is limited to those who have the proper training certificates. In this way the segment of teaching professions is in itself again highly segmentated ${ }^{8}$.

The competition structure in the segment for occupations in non-medical laboratory (appendix, table 4 ) is clearly an example of a craftspecific labour market. The segment is open for those who are trained for technical, biological and chemical laboratory functions at an intermediate and higher vocational level.

The same holds for the segment of the lower and intermediate agricultural occupations (appendix, table 5). This segment is dominated by LVE Agriculture and IVE Agriculture. Interesting here is the position of HVE Agriculture. Although the main segment for this training is formed by the higher agricultural occupations (appendix, table 18), it also competes with the lower and intermediate types of training in this segment.

The segment of theological professions clearly indicates a craftspecific labour market (appendix, table 6). The segment is completely dominated by the theology types of training at the higher vocational and academic level.

The engineering occupations can be distinguished into two different segments (appendix, tables 7 and 8): the occupations in which higher vocational and academic types of training in engineering dominate and the occupations in which the lower and intermediate types of training dominate. Interesting in the first segment is the position of HVE Business Administration Technology. The main segment for this training is the segment of business administration (appendix, table 19). The loading of this training in 1985 may well reflect changing characteristics of the higher engineering functions: less production and more management. The competition structure in 1979 clearly indicates a craftspecific labour market, with substitution possibilities limited to one sector of education. With regard to the structure in 1985, one could say that the boundary between engineering and business administration is becoming less sharp, thus introducing more competition with other types of training. The loadings of primary education in the lower and intermediate engineering segment indicates that some occupations in this segment are unskilled labour.

One can find the same phenomenon in the segments of lower community care and lower transport (appendix, tables 9 and 10). These segments show in general more competition between types of training. Although they are dominated by LVE and (to a lesser extent) IVE types of training in community care and transport respectively, there is also competition from

8. In Borghans (1992) this classification problem for teaching professions is solved by the introduction of a different teaching profession for every type of education. This solution, however, reintroduces a priori segmentations at the labour market without empirical validation. 
other types of training, mainly from primary education and other LVE types of training. This shows that in the lower segments of the labour market, specific training certificates are not always required to enter a job. The segment of lower transport shows an increase in the qualification requirements, which is indicated by a higher loading of IVE Transport, Harbour and Telecommunications in 1985 and a lower loading of Primary Education. In the segment of lower community care the opposite seems to be the case. Here we see a lower loading in 1985 of IVE Community Care and a higher loading of Primary Education.

The segment of social and cultural occupations (appendix, table 11) is again an example of a craft specific labour market with substitution possibilities limited to one sector. The fact that $A E$ Social and Cultural shows an increase of loading between 1979 and 1985 seems to indicate processes of displacement and filtering down the labour market.

The segment of occupations related to fine arts and social sciences (appendix, table 12) is the first segment where competition is restricted to one level and involves multiple sectors of education. It refers to more general occupations on an academic level.

The segments for police and defence, nursing and paramedical occupations, law and administration and higher transport (appendix, tables 13 till 16) show very similar characteristics. Within each of these segments two types of training occur, both belonging to the same sector of education. In the case of law and administration, the segment is dominated by the academic training over its higher vocational counterpart. In the case of higher transport, the higher vocational training dominates over its intermediate counterpart. In the other two segments the loadings of the two types of intermediate and higher vocational education are alike. The competition structure in all four segments seems to indicate a labour market where emphasis is put on specific skill requirements. The decreases in the loadings of the HVE and IVE training in the segments of law and administration and higher transport respectively, indicates that during the 80 's higher requirements have been set by employers.

The segment for hotel and catering (appendix, table 17) presents an interesting case. In the 1979 analysis only one segment is distinguished in which hotel and catering types of training at intermediate and higher vocational level dominate. In the 1985 analysis, two different segments are distinguished, one for the training at intermediate level and one for the training at higher vocational level. This indicates a polarization in this segment of the labour market.

The segment for higher agricultural occupations (appendix, table 18) is dominated by the higher vocational and academic agricultural studies. Interesting fact is that the segment has become more important for both types of training, as is reflected in the higher loadings in 1985. As is mentioned earlier, the HVE Agriculture also loads on the segment of lower and intermediate agricultural occupations.

The segment of business administration (appendix, table 19) used to be a segment dominated by $A E$ Econom(etr)ics and Business Administration, with only limited competition from the HVE 
Commerce and Administration. A separate segment was formed by the HVE Business Administration Technology. In 1985 however only one segment is distinguished. HVE Business Administration Technology has therefore managed to break open two relatively distinct segments of the labour market: the segment of higher engineering and the segment of business administration. It illustrates the fact that relatively new types of training can succesfully operate on the labour market, even within existing segments.

The segment of performers and artists (appendix, table 20) is dominated by the HVE Fine Arts, with only limited competition from AE Fine Arts. The competition from the latter stems from the academically trained restorers, who are coded in the same occupation as artists. This segment shows the features of a craft specific labour market segment.

The remaining segments of higher medical laboratory, intermediate medical laboratory, medical professions, pharmacy and lower security (appendix, tables 21 till 25) represent labour market segments ruled by credentials. Access to the jobs belonging to these segments is permitted only to people who hold the proper credentials. 


\section{CONCLUSIONS}

In this paper the competition structure of types of training on the labour market is examined, using data from the Dutch Labour Force Survey of 1979 and 1985. In examining this competition structure, it is tried to grasp one of the essential elements of the labour market position of types of training: that is the positioning of a type of training with regard to other types of training. Notably, this is rarely done in labour market research. Usually, the labour market position of a type of training is investigated by looking at indicators like unemployment rate, mean income or mean function level, for each training separately. On a labour market where competition and substitution takes place, these indicators can, however, not be understood as results of the supply and demand for that particular training, but arise in the interaction with the supply of related types of training and the demand for related occupations. One can even state that in this respect, previous research, implicitly, holds naive conceptions of the relation between education and labour market, assuming either full competition or an exclusive relation.

Competition is the essence of selection processes on the labour market and it is this process which has typically been neglected in previous research. The basic questions in this respect are: who competes with who and for which job? In examining this competition structure some specific methods to analyse the substitution possibilities between types of training have been introduced. The basic idea is that these substitution possibilities can be derived from the similarity of the distributions of the types of training over the different occupations. Factor analysis is used to reduce the amount of information and to identify the underlying structure.

Ideally, three types of segments are expected to be distinguished. The first type involves those segments where the emphasis is put on specific rather than generic skills. The substitution possibilities in these segments are restricted to one sector of education, but involve multiple levels. The second type involves the segments where people are screened on their general abilities rather than their specific skills. The level of education is therefore dominant, but within this level substitution may take place between different sectors of education. The third type involves the segments ruled by credentialism. Here an exclusive relation between a type of training and an occupation exists and by rule there are no substitution possiblities.

The analysis shows that there is a considerable degree of substitution or competition on the labour market. A rough indicator of the degree of competition amounts to some $40 \%$. This indicates that neither the assumption of an exclusive relation between training and occupation (which would yield a score of $0 \%$ ) nor the assumption of total flexibility (which would yield a score of $100 \%$ competition), can be called realistic. The truth is somewhere in between. There is a high degree of segmentation of the labour market along qualification lines and competetion is mainly restricted to substitution within these segments.

Most of the segments to be distinguished belong to what above has been referred to as the craft specific labour markets and the segments ruled by credentials. The majority of types of 
training (25 out of 54) belong to one of the twelve craft specific segments. These typically involve two or three types of training at intermediate or higher vocational level that belong to the same sector of education (like engineering, agriculture, transport etc.). Ten types of training can be said to have an exclusive position on the labour market. These types of training aim at the professionalised segments of the labour market and involve occupations like teachers, medical and pharmaceutical professions, and security.

At the lower level of the labour market three different segments are distinguished: technical, community care and transport. All three segments involve both semi-skilled as well as unskilled occupations. Substitution takes place between lower vocational types of training and primary education.

Finally, a large segment of economic administrative occupations has been distinguished. This segment involves seven types of training from multiple sectors as well as multiple levels. It is a typical example of a sector where much emphasis is put on general skills, and where the boundaries between the different occupations are not very sharp. This causes a great deal of competition between the different types of training.

The occurence of craft specific segments and the absence of segments where there is competition between multiple sectors, but within one level, has to be explained further. One possible problem that makes it difficult to distinguish the general segments is the nature of the data used. The labour force census contains people from the complete labour force from all cohorts. The selection based on screening, which might particulary be expected in the general segments might, however, change over the years. The present data therefore contain a mix of different screening strategies instead of one clearly observable screening rule. It might therefore be interesting to perform these analysis with data specific on a single cohort of schoolleavers.

Furthermore, the analysis in this paper is to a large extent only descriptive. In future research we will address, for a good understanding of the selection processes, both the measurement techniques and the theoretical underpinning of the substitution process which take place at the labour market. Furthermore we will address other aspects of the labour market position like unemployment rate, or mean income. In conjunction with the present analysis on the competition structure, these indicators will show which types of training belong to the 'winners' or 'losers' within a particular segment of the labour market.

For an adequate investigation of these substitution processes at the labour market it is, however, a prerequisit to posses a description of the segments at the market. This article provides a way to observe these segments and has shown that it is indeed relevant to distinguish such labour market segments. 


\section{REFERENCES}

Bakker, B.F.M. (1987), 'Onderwijs en de kans op werkloosheid'. Paper Centraal Bureau voor de Statistiek.

Becker, G. (1964), Human Capital. A Theoretical and Empirical, with Special Reference to Education. Princeton.

Blaug, M. (1967), 'Approaches to Educational Planning'. The Economic Journal, 76, pp. 262287.

Borghans, L. (1992), 'A Histo-Topographic Map of Dutch University Studies'. Maastricht, ROAWorking Paper-1992/5E.

Centraal Bureau voor de Statistiek (1985), Beroepenclassificatie 1984. Lijst van benamingen per beroepencode. Voorburg: CBS.

Collins, R. (1979), The Credential Society. New York: Academic Press.

De Grip, A., and J.A.M. Heijke (1988), 'Labour-Market Indicators: An Inventory'. Maastricht, ROA-Working Paper-1988/1E.

Ganzeboom, H.B.G. and P.M. de Graaf (1989), 'Verandering van onderwijskansen in Nederland tussen 1900 en 1980'. Mens en Maatschappij, boekaflevering, pp. 58-78.

Glebbeek, A.C. (1983), 'Jeugdwerkloosheid en het onderwijs'. Jeugd en Samenleving, 13, 5-6, pp. 373-389.

Glebbeek, A.C. and Th. Mensen (1986), 'Waar ligt de sleutelmacht van de school?' Paper presented at 'De Sociologendagen'. Groningen: Sociologisch Instituut.

Hartog, J. (1993), 'On Human Capital and Individual Capabilities'. Paper presented at the EALEconference, Maastricht.

Hartog, J, H. van Ophem and G. Pfann (1985). Allocatie en beloning. OSA-Werkdocument 11.

Hoof, J. van (1987), De arbeidsmarkt als arena. Amsterdam: SUA.

Hoof, J. van and J. Dronkers (1980), Onderwijs en arbeidsmarkt, Deventer: Van Loghum Slaterus.

Kim, J.O. (1975), 'Factor Analysis'. In: N.H. Nie et al. SPSS. Statistical Package for the Social Sciences. New York: McGraw-Hill. 
Lorr, M. (1983), Cluster Analysis for Social Scientists. San Fransisco.

Meesters and Van de Pol (1988), 'Een baan vinden, een baan verliezen'. Paper Centraal Bureau voor de Statistiek.

Ministerie van Sociale Zaken en Werkgelegenheid (1988), Rapportage Arbeidsmarkt 1988. Den Haag: SoZaWe.

Schultz, T.W. (1961), 'Investment in Human Capital'. American Economic Review, vol. 51, pp. $1-17$.

Spence, O.F. (1973), 'Job Market Signalling'. Quarterly Journal of Economics, pp. 355-374.

Stiglitz, J.E. (1975), 'The Theory of Screening, Education and Distribution of Income'. American Economic Review 66, pp. 283-300.

Thurow, L.C. (1975), Generating Inequality. New York: Basic Books.

Van Eijs, P. (1993), 'The Manpower Requirements Approach: Background and Methodology'. Maastricht, ROA-Research Memorandum-1993/3E. 


\section{APPENDIX}

Table 2. Economic-administrative occupations (factorloadings and eigenvalue)

\begin{tabular}{lcc}
\hline Training & $\begin{array}{c}1979 \\
\text { factor } 1\end{array}$ & $\begin{array}{c}1985 \\
\text { factor } 1\end{array}$ \\
\hline & & .87 \\
Lower General Secondary Education & .91 & .94 \\
Higher General Secondary Education & .91 & .90 \\
LVE Commerce and Administration & .86 & .93 \\
IVE Commerce and Administration & .93 & .70 \\
HVE Commerce and Administration & .70 & .79 \\
IVE Administrative, Legal and Fiscal & .70 & .63 \\
HVE Administrative, Legal and Fiscal & $.32^{*}$ & $.29^{*}$ \\
LVE Community Care, Hotel and Catering & $.36^{*}$ & $.33^{*}$ \\
IVE Transport, Harbour and Telecommunications & $.44^{*}$ & $.35^{*}$ \\
HVE Interpreter and Translator & $.29^{*}$ & $.34^{*}$ \\
HVE Business Administration Technology & $.17^{*}$ & .83 \\
HVE Rest & $.37^{*}$ & $.07^{*}$ \\
Rest & .59 & 10.29 \\
& & 19.1
\end{tabular}

Table 3. Teaching professions (factorloadings and eigenvalue)

\begin{tabular}{|c|c|c|c|}
\hline \multirow[t]{2}{*}{ Training } & \multicolumn{2}{|c|}{1979} & \multirow{2}{*}{$\begin{array}{l}1985 \\
\text { factor } 2\end{array}$} \\
\hline & factor 2 & factor 28 & \\
\hline HVE Interpreter and Translator & .86 & $-.05 *$ & .70 \\
\hline HVE Teacher Training & $.44^{*}$ & .87 & .83 \\
\hline AE Teacher Training & .89 & $.21 *$ & .96 \\
\hline AE Arts & .97 & $.06 *$ & .97 \\
\hline AE Mathematics and Natural Sciences & .86 & $.07 *$ & .85 \\
\hline AE Agriculture & $.42 *$ & $.04 *$ & $.31 *$ \\
\hline AE Engineering & $.24 *$ & $.02 *$ & $.41^{*}$ \\
\hline AE Econom(etr)ics and Business Administration & $.22 *$ & $.03 *$ & $.37 *$ \\
\hline AE Fine Arts & $.09 *$ & $.07 *$ & $.37 *$ \\
\hline AE Social Sciences & $.29 *$ & $-.01 *$ & $.44^{*}$ \\
\hline AE Rest & .51 & $.23^{*}$ & .87 \\
\hline eigenvalue: & 4.90 & .64 & 5.32 \\
\hline pct. of var.: & 9.1 & 1.2 & 9.9 \\
\hline
\end{tabular}


$-19-$

Table 4. Non-medical laboratory (factorloadings and eigenvalue)

\begin{tabular}{lcc}
\hline Training & $\begin{array}{c}1979 \\
\text { factor } 3\end{array}$ & $\begin{array}{c}1985 \\
\text { factor } 5\end{array}$ \\
\hline IVE Non-medical laboratory & .96 & .97 \\
HVE Non-medical laboratory & .97 & .95 \\
HVE Rest & .76 & $.22 *$ \\
$\quad$ pct. of var.: & 2.75 & 2.19 \\
& 5.1 & 4.1 \\
* not main factor for training in question & & \\
\hline
\end{tabular}

Table 5. Lower and intermediate agricultural occupations (factorloadings and eigenvalue)

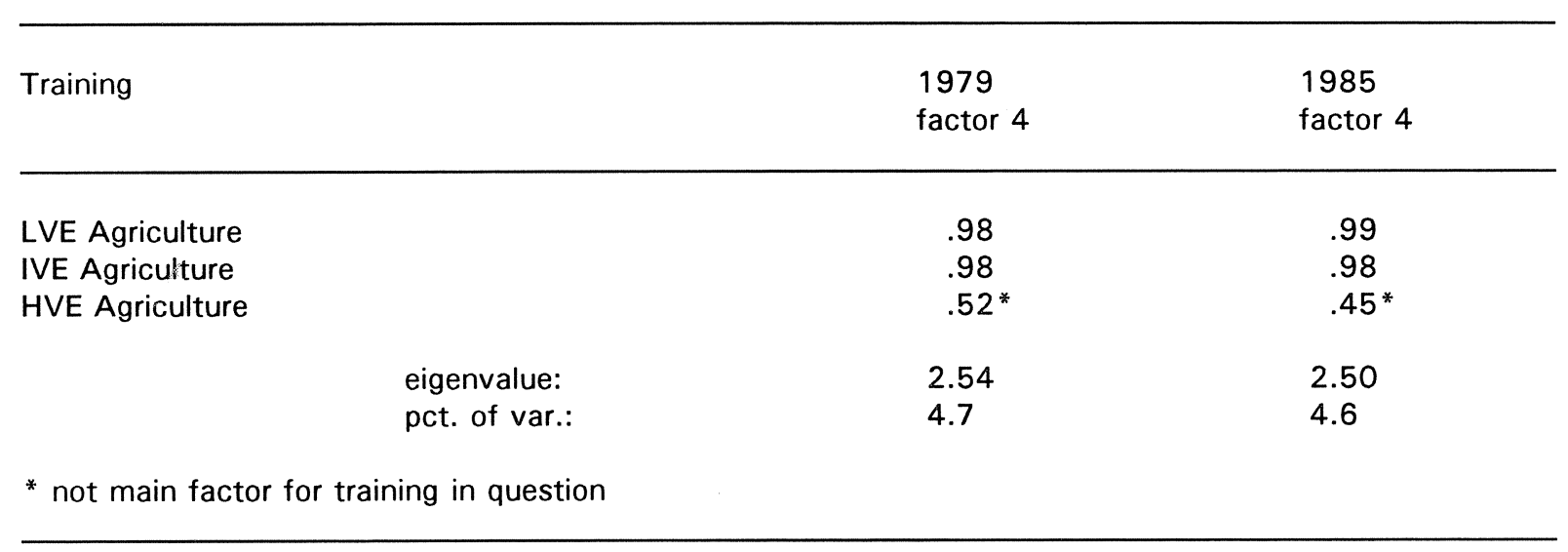

Table 6. Theological professions (factorloadings and eigenvalue)

\begin{tabular}{|c|c|c|c|}
\hline Training & & $\begin{array}{l}1979 \\
\text { factor } 5\end{array}$ & $\begin{array}{l}1985 \\
\text { factor } 6\end{array}$ \\
\hline HVE Theology & & .99 & .99 \\
\hline \multirow[t]{3}{*}{ AE Theology } & & .99 & .99 \\
\hline & eigenvalue: & 2.08 & 2.05 \\
\hline & pct. of var.: & 3.9 & 3.8 \\
\hline
\end{tabular}


Table 7. Higher engineering (factorloadings and eigenvalue)

\begin{tabular}{|c|c|c|}
\hline Training & $\begin{array}{l}1979 \\
\text { factor } 6\end{array}$ & $\begin{array}{l}1985 \\
\text { factor } 7\end{array}$ \\
\hline $\begin{array}{l}\text { HVE Engineering } \\
\text { AE Engineering } \\
\text { HVE Business Administration Technology }\end{array}$ & $\begin{array}{l}.93 \\
.92 \\
.04^{*}\end{array}$ & $\begin{array}{l}.91 \\
.84 \\
.43^{*}\end{array}$ \\
\hline $\begin{array}{l}\text { eigenvalue: } \\
\text { pct. of var.: }\end{array}$ & $\begin{array}{l}1.99 \\
3.7\end{array}$ & $\begin{array}{l}1.92 \\
3.6\end{array}$ \\
\hline * not main factor for training in question & & \\
\hline
\end{tabular}

Table 8. Lower and intermediate engineering (factorloadings and eigenvalue)

\begin{tabular}{|c|c|c|}
\hline Training & $\begin{array}{l}1979 \\
\text { factor } 7\end{array}$ & $\begin{array}{l}1985 \\
\text { factor } 9\end{array}$ \\
\hline LVE Technical & .84 & .84 \\
\hline IVE Engineering & .92 & .90 \\
\hline Primary education & $.37 *$ & $.34^{*}$ \\
\hline $\begin{array}{l}\text { eigenvalue: } \\
\text { pct. of var.: }\end{array}$ & $\begin{array}{l}1.93 \\
3.6\end{array}$ & $\begin{array}{l}1.64 \\
3.0\end{array}$ \\
\hline
\end{tabular}

Table 9. Lower community care (factorloadings and eigenvalue)

\begin{tabular}{lcc}
\hline Training & $\begin{array}{c}1979 \\
\text { factor } 8\end{array}$ & $\begin{array}{c}1985 \\
\text { factor } 3\end{array}$ \\
\hline & & .89 \\
LVE Community Care, Hotel and Catering & .84 & .67 \\
IVE Community Care & .80 & .72 \\
Primary education & $.43^{*}$ & $.40^{*}$ \\
Lower General Secondary Education & $.23^{*}$ & $.33^{*}$ \\
LVE Commerce and Administration & $.25^{*}$ & .73 \\
LVE Rest & $.23^{*}$ & 3.02 \\
$\quad$ eigenvalue: & 1.88 & 5.6 \\
pct. of var.: & 3.5 & \\
* not main factor for training in question & & \\
\hline
\end{tabular}


Table 10. Lower transport (factorloadings and eigenvalue)

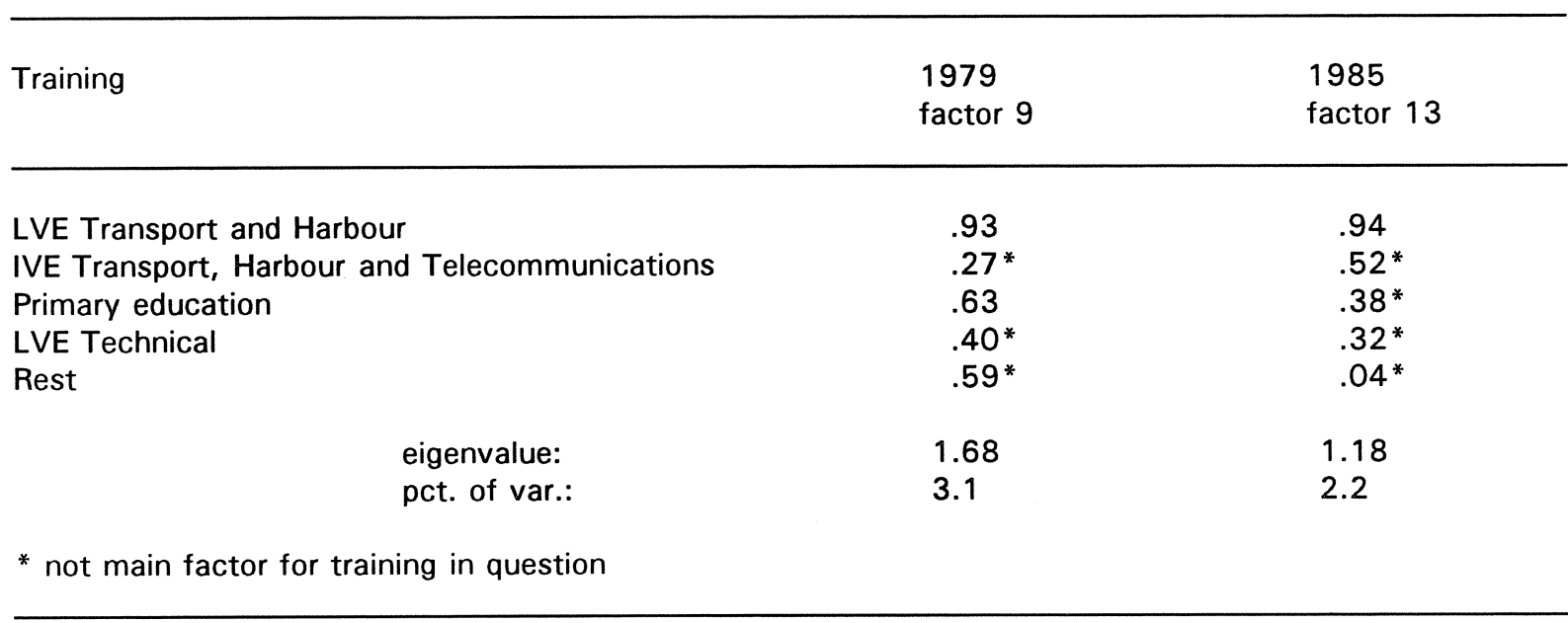

Table 11. Social and Cultural (factorloadings and eigenvalue)

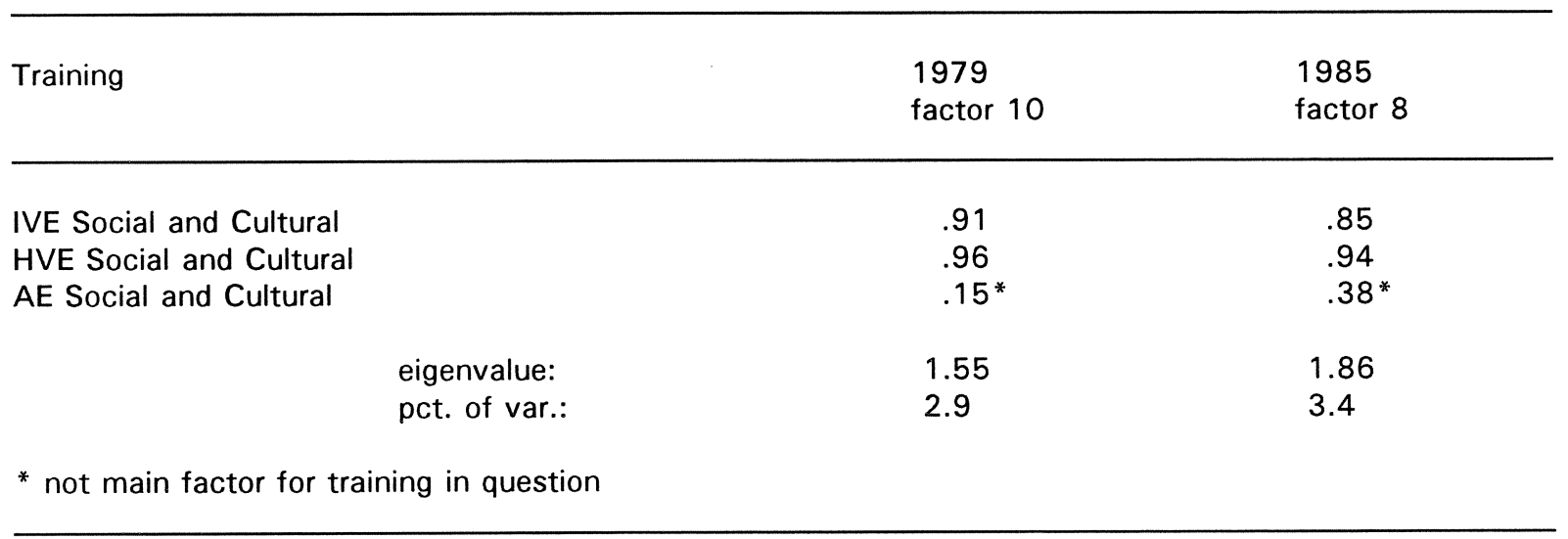

Table 12. Fine arts and Social Science (factorloadings and eigenvalue)

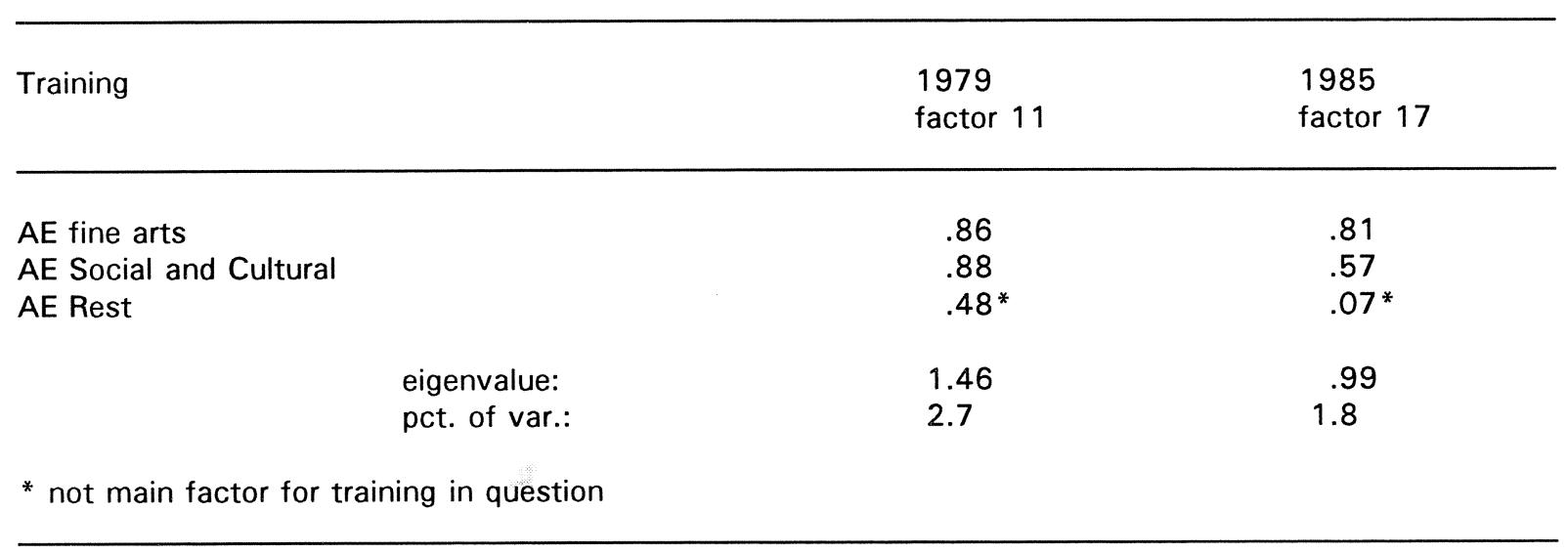


Table 13. Police and defence (factorloadings and eigenvalue)

\begin{tabular}{lcc}
\hline Training & $\begin{array}{c}1979 \\
\text { factor } 12\end{array}$ & $\begin{array}{c}1985 \\
\text { factor } 12\end{array}$ \\
\hline $\begin{array}{l}\text { IVE Police, Fire and Defence Forces } \\
\text { HVE Police, Fire and Defence Forces }\end{array}$ & .89 & .87 \\
eigenvalue: & .89 & .87 \\
pct. of var.: & 1.40 & 1.21 \\
\hline
\end{tabular}

Table 14. Nursing and paramedical (factorloadings and eigenvalue)

\begin{tabular}{|c|c|c|}
\hline Training & $\begin{array}{l}1979 \\
\text { factor } 13\end{array}$ & $\begin{array}{l}1985 \\
\text { factor } 10\end{array}$ \\
\hline IVE Paramedical services & $\begin{array}{r}.87 \\
87\end{array}$ & .90 \\
\hline HVE Nursing and Physiotherapy etc. & .87 & .93 \\
\hline eigenvalue: & 1.38 & 1.54 \\
\hline pct. of var.: & 2.6 & 2.9 \\
\hline
\end{tabular}

Table 15. Law and administration (factorloadings and eigenvalue)

\begin{tabular}{lcc}
\hline Training & $\begin{array}{c}1979 \\
\text { factor } 14\end{array}$ & $\begin{array}{c}1985 \\
\text { factor } 16\end{array}$ \\
\hline AE Law and Public Administration & .94 & .96 \\
HVE Administrative, legal and Fiscal & .75 & $.44^{*}$ \\
eigenvalue: & 1.00 \\
pct. of var.: & 1.29 & 1.9 \\
\hline
\end{tabular}


Table 16. Higher Transport (factorloadings and eigenvalue)

\begin{tabular}{lcc}
\hline Training & $\begin{array}{c}1979 \\
\text { factor } 15\end{array}$ & $\begin{array}{c}1985 \\
\text { factor } 14\end{array}$ \\
\hline IVE Transport, Harbour and Telecommunications & .75 & .67 \\
HVE Air, Sea and Land transport & .91 & .94 \\
$\quad$ eigenvalue: & 1.28 & 1.12 \\
pct. of var.: & 2.4 & 2.1 \\
\hline
\end{tabular}

Table 17. Hotel and Catering (factorloadings and eigenvalue)

\begin{tabular}{|c|c|c|c|}
\hline Training & $\begin{array}{l}1979 \\
\text { factor } 16\end{array}$ & factor 18 & 5 factor 20 \\
\hline $\begin{array}{l}\text { IVE Hotel, Catering and Hairdressing } \\
\text { HVE Hotel and Catering Industry }\end{array}$ & $\begin{array}{l}.88 \\
.80\end{array}$ & $\begin{array}{l}.97 \\
.12\end{array}$ & $\begin{array}{l}.12^{*} \\
.95\end{array}$ \\
\hline $\begin{array}{l}\text { eigenvalue: } \\
\text { pct. of var.: }\end{array}$ & $\begin{array}{l}1.07 \\
2.0\end{array}$ & $\begin{array}{l}.98 \\
1.8\end{array}$ & $\begin{array}{l}.96 \\
1.8\end{array}$ \\
\hline * not main factor for training in question & & & \\
\hline
\end{tabular}

Table 18. Higher agricultural occupations (factorloadings and eigenvalue)

\begin{tabular}{|c|c|c|c|}
\hline Training & & $\begin{array}{l}1979 \\
\text { factor } 17\end{array}$ & $\begin{array}{l}1985 \\
\text { factor } 11\end{array}$ \\
\hline $\begin{array}{l}\text { HVE Agriculture } \\
\text { AE Agriculture }\end{array}$ & & $\begin{array}{l}.71 \\
.87\end{array}$ & $\begin{array}{l}.81 \\
.90\end{array}$ \\
\hline & $\begin{array}{l}\text { eigenvalue: } \\
\text { pct. of var.: }\end{array}$ & $\begin{array}{l}1.04 \\
1.9\end{array}$ & $\begin{array}{l}1.43 \\
2.6\end{array}$ \\
\hline
\end{tabular}


Table 19. Business administration (factorloadings and eigenvalue)

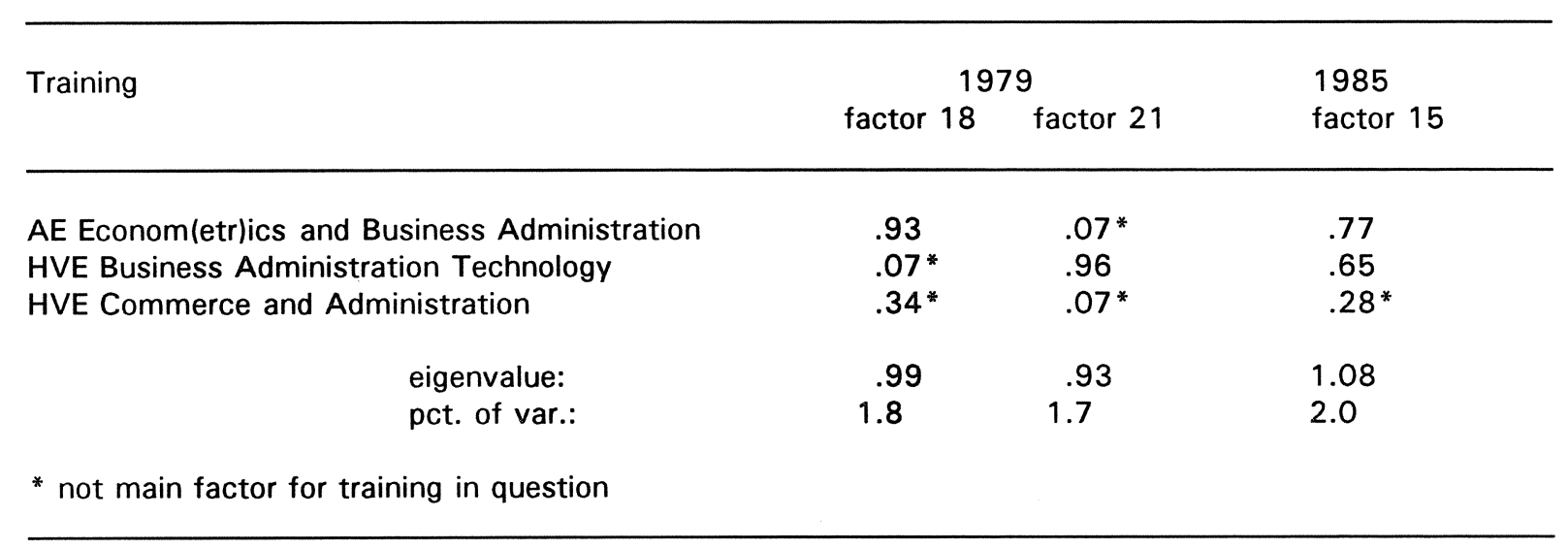

Table 20. Performers and artists (factorloadings and eigenvalue)

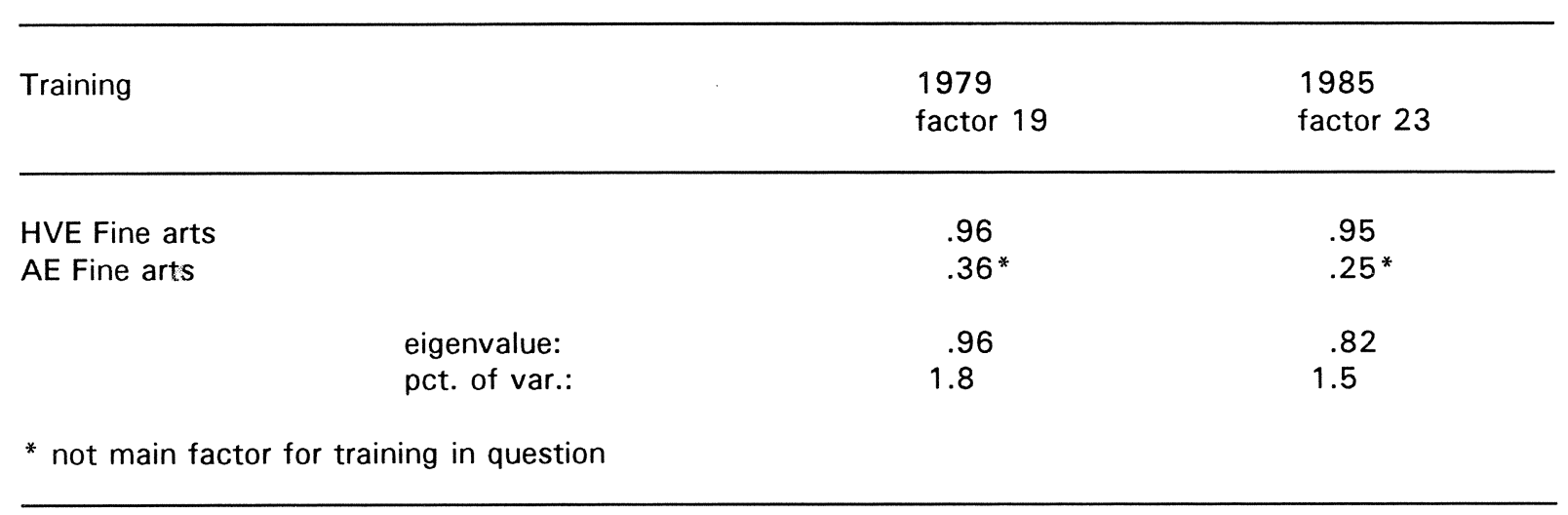

Table 21. Higher medical laboratory (factorloadings and eigenvalue)

\begin{tabular}{|c|c|c|}
\hline Training & $\begin{array}{l}1979 \\
\text { factor } 20\end{array}$ & $\begin{array}{l}1985 \\
\text { factor } 19\end{array}$ \\
\hline HVE Medical laboratory & .96 & .96 \\
\hline $\begin{array}{l}\text { eigenvalue: } \\
\text { pct. of var.: }\end{array}$ & $\begin{array}{l}.94 \\
1.7\end{array}$ & $\begin{array}{l}.97 \\
1.8\end{array}$ \\
\hline
\end{tabular}


Table 22. Medical professions (factorloadings and eigenvalue)

\begin{tabular}{|c|c|c|}
\hline Training & $\begin{array}{l}1979 \\
\text { factor } 22\end{array}$ & $\begin{array}{l}1985 \\
\text { factor } 22\end{array}$ \\
\hline $\begin{array}{l}\text { AE Veterinary and Medical Sciences } \\
\text { and Dentistry }\end{array}$ & .98 & .99 \\
\hline $\begin{array}{l}\text { eigenvalue: } \\
\text { pct. of var.: }\end{array}$ & $\begin{array}{l}.89 \\
1.6\end{array}$ & $\begin{array}{l}.90 \\
1.7\end{array}$ \\
\hline
\end{tabular}

Table 23. Lower Security (factorloadings and eigenvalue)

\begin{tabular}{|c|c|c|c|}
\hline Training & & $\begin{array}{l}1979 \\
\text { factor } 23\end{array}$ & $\begin{array}{l}1985 \\
\text { factor } 21\end{array}$ \\
\hline \multirow[t]{2}{*}{ LVE Security } & & .99 & .99 \\
\hline & $\begin{array}{l}\text { eigenvalue: } \\
\text { pct. of var.: }\end{array}$ & $\begin{array}{l}.87 \\
1.6\end{array}$ & $\begin{array}{l}.94 \\
1.7\end{array}$ \\
\hline
\end{tabular}

Table 24. Pharmacy (factorloadings and eigenvalue)

\begin{tabular}{|c|c|c|c|}
\hline Training & & $\begin{array}{l}1979 \\
\text { factor } 24\end{array}$ & $\begin{array}{l}1985 \\
\text { factor } 26\end{array}$ \\
\hline \multirow[t]{2}{*}{ AE Pharmacy } & & .99 & .97 \\
\hline & $\begin{array}{l}\text { eigenvalue: } \\
\text { pct. of var.: }\end{array}$ & $\begin{array}{l}.80 \\
1.5\end{array}$ & $\begin{array}{l}.68 \\
1.3\end{array}$ \\
\hline
\end{tabular}

Table 25. Intermediate medical laboratory (factorloadings and eigenvalue)

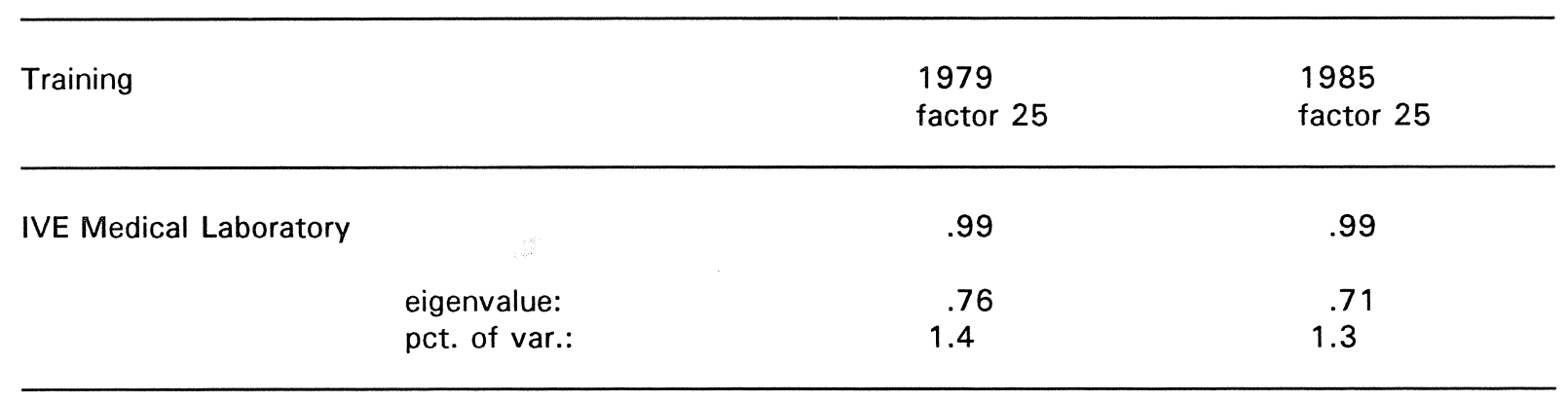

